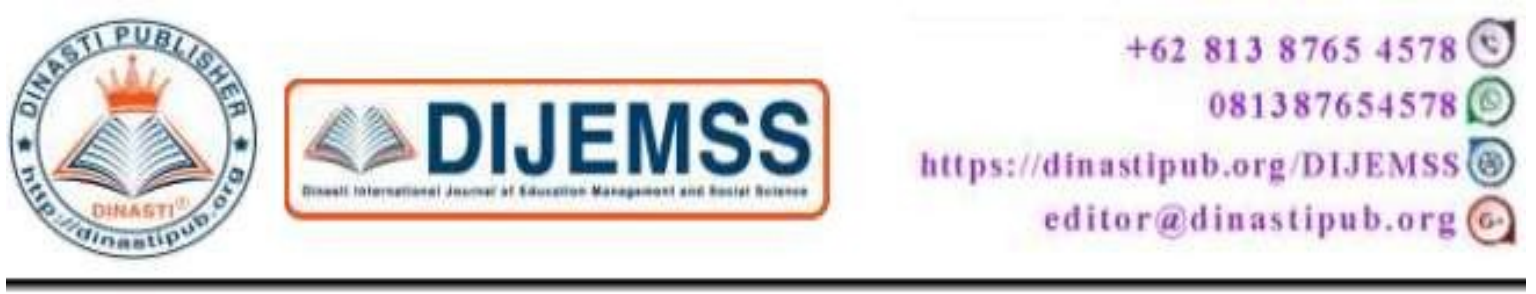

\title{
THE EFFECT OF NON PERFORMING LOANS TO CASH RATIO ON BANK BPR KERTARAHARJA
}

\section{Winna Roswinna ${ }^{1}$, Feby Febrian ${ }^{2}$, Granit Agustina $^{3}$, Maria Lusiana Yulianti ${ }^{4}$, Anne Lasminingrat $^{5}$ 1,2,3,4,5,6) Fakultas Ekonomi \& Bisnis Universitas Winaya Mukti}

\begin{tabular}{|c|c|}
\hline $\begin{array}{l}\text { ARTICLE INFORMATION } \\
\text { Received: } 1 \text { February } 2020 \\
\text { Revised: } 7 \text { February } 2020 \\
\text { Issued: } 20 \text { February } 2020 \\
\text { Corresponding author: } \\
\text { Winna Roswinna } \\
\text { E-mail: } \\
\text { Obelix9009@gmail.com } \\
\text { DOI:10.31933/DIJEMSS }\end{array}$ & $\begin{array}{l}\text { Abstract: In this study there are two variables, } \\
\text { namely variable X (NPL) and Y variable (CR). This } \\
\text { research was conducted to determine the effect of } \\
\text { NPL on CR Bank BPR Kertaraharja. The method } \\
\text { used in this research is descriptive analysis method to } \\
\text { identify how the influence of NPL and how big CR is } \\
\text { at Kertaraharja Rural Bank. While the verification of } \\
\text { the analysis to identify the problem is how much } \\
\text { influence the NPL has on the CR of BPR Kertraharja } \\
\text { bank. This research was conducted at the BPR } \\
\text { Kertaraharja Bank office. This research was } \\
\text { conducted using a sample based on Purpose } \\
\text { Sampling. The hypothesis of this study is that NPL } \\
\text { has an effect on CR at the BPR Kertaraharja Bank. } \\
\text { To measure the effect of these variables using Simple } \\
\text { Linear Regression with the help of the application } \\
\text { software system SPSS } 21.0 \text {. Based on the results of } \\
\text { data analysis using statistical methods, it was } \\
\text { concluded that there was a significant influence } \\
\text { between NPLs on CR banks, this was based on } \\
\text { regression analysis with the equation Y = } 24,985 \text { - } \\
1,312 X \text {. In correlation there is a fairly strong } \\
\text { relationship between NPL and bank CR with a value } \\
\text { of } 0.680 \text {. Then the coefficient of determination (KD) } \\
\text { is obtained that the NPL affects the CR with a value } \\
\text { of } 46.3 \% \text {. Test the hypothesis of this study in which } \\
\text { the } t \text { count of } 4,147 \text { is greater than the t table value of } \\
2012 . \text { Then H1 is accepted and H0 is rejected, which } \\
\text { means that NPL has a strong influence on bank CR. } \\
\text { Keywords: NPL, CR }\end{array}$ \\
\hline
\end{tabular}




\section{INTRODUCTION}

Southeast Asia is a region with a number of countries reaching 11 independent countries with various forms of government systems ranging from the public system to still adhere to the royal system until now, economic growth in this region is very conducive and interesting, the flow of distribution of abarang and services that bring together four continent and 2 oceans are very aggressive in order to meet the needs of all citizens in the Southeast Asia region. At the beginning of 2020, a schedule formed in the economics of Southeast Asian countries had the objective to eliminate or reduce various obstacles and obstacles both from within and from outside carrying out economic activities across regions, including in trade in goods and services, especially investment on an infrastructure. Southeast Asian economy citizens in 2020 have a broad economic scope along with the increasing need for these goods and services so that they have strategic economic coverage.

In 2020 ASEAN economic growth has a very real impact on the growth and development of the business world in Indonesia, because it not only creates a free market for trade in goods and services, but also touches on other economies such as health, mining employment, business competition policy and other aspects that are very relevant for Indonesia's development, such as ambition to build and empower Infrastructure in ASEAN to increase trade mobility and the flow of human resources in the region. Therefore the presence of a bank as a company or financial institution is very important for the economy of a country that serves to facilitate financial traffic in the movement, development and economic growth of a country as part of a monetary system that has a strategic position on economic development. Public trust in a bank can be seen from the assets of a bank that must always be maintained in order to prevent the occurrence of rush and chaos to a number of customers. Then the bank is expected to be able to manage the risks it has including its income, it is expected that the bank's return can increase. Therefore, if there is a risk that is not possible to be managed properly, it will potentially increase the probability for the banks themselves. With such potentials and circumstances, it can cause a company to go bankrupt and eventually it must be liquidated with the reason to get such a large amount of loss. This happens because it does not or fails to take into account any problems or risks, including the existence of various problems within the company or the bank itself. There are several ways or methods of various analytical techniques, including how various financial ratios that can be done or used in making or evaluating the performance of a bank relating to existing problems. Ratios of ratios that have a value or a benefit can show and show a change in conditions where the financial or operating performance of a company has or illustrates the trends and patterns and ways of these changes, which in turn, can show the analysis of opportunities, risks and problems that arise for the company that is being reviewed. Revenue (profits), in some studies using financial ratios such as Cash Ratio (CR). Then CR was chosen as the dependent variable in this study. One of the financial ratios that generally affects CR is NPL or Non Performing Loans (representing credit risk), namely credit management where banks also need to pay attention to the amount of Non Performing Loans (NPLs) or problems in a loan that can interfere with the stability of banking operations. This increase in NPL if allowed to continue will negative effect on the bank. One of the negative impacts is reducing the amount of capital owned by banks. 


\section{LITERATURE REVIEW}

Non Performing Loans is a percentage of total non-performing loans (criteria of substandard, doubtful, loss) of the total loans extended by banks (Ali, 2004: 33). Non Performing Loans reflect the credit ratio. The smaller the Non Performing Loans, the smaller the credit risk borne by the bank. Banks in conducting credit must conduct an analysis of the ability of debtors to repay their obligations. After credit is granted, banks are required to monitor the use of credit and the ability and compliance of debtors in fulfilling their obligations. The bank conducts a review and binding of collateral to minimize credit risk (Ali, 2004: 48). According to Erna Sari, Suhadak suhadak, Sri Mangesti Rahayu, Solimun Solimun (2018), The performance of Indonesian banks remains an interesting topic to explore. This research is focused on Indonesian commercial banks. The performance of Indonesian banks in the last few years fluctuated. This occurs because of several things, such as a slow down in the global economy, weakening of the rupiah, decreased commodity prices, and market conditions that also affect bank performance. Data from the Financial Services Authority (OJK) shows that the profit generated by the national commercial banks in 2015 decreased. The decline was resulted from the credit risk, in which a great number of bank debtors failed to meet their obligations on the due date. This leads to an increasing rate of Non Performing Loans (NPL). The higher the rate of NPL, the higher the allowance for impairment losses is, resulting in the increasingly reduced earnings after tax. Risk management through the internal quality system strongly supports banks' financial performance, including income and profitability through significant equity savings in banking practices. Risk management is one of the key issues in stabilizing this system, through internal appraisal tailored to the conditions of new regulation (Cipovová \& Belás, 2014). Cash Ratio or often also called Cash Asset Ratio is a ratio used to compare the total cash (cash) and cash equivalent of a company with its current liabilities. This Cash Ratio is basically a refinement of the quick ratio that is used to identify the extent to which funds (cash and cash equivalents) are available to pay off obligations

Current or short-term debt. Prospective creditors use this ratio as a measure of company liquidity and how easily the company can cover its short-term debt obligations. This Cash Ratio is the most strict and conservative liquidity ratio to the company's ability to cover its debt or short-term liabilities when compared to other liquidity ratios (current ratio and fast ratio). This is because the Cash Ratio only calculates the most liquid short-term liquid assets or assets, which are the easiest and fastest cash and cash equivalents to be used in paying off current debts. Cash Ratio is calculated by distributing the most liquid current assets, namely cash and cash equivalents with its current liabilities. Cash ratios are actually not very popular in liquidity analysis such as current ratios and fast ratios because their use is also very limited. Basically, there is no general assessment of this cash ratio. In some countries, a cash ratio of 0.2 is considered acceptable. A cash ratio that is too high can indicate that the use of assets is not optimal for the company because it holds too much cash in its balance sheet. Performance determined by adequate efficiency and competition of financial institutions is crucial for users of bank services. According to Peter Cleary Martin Quinn (2016) The success of modern firms partially depends upon their ability to invest in new technologies that facilitate the exploitation of new commercial opportunities and / or improved incumbent business processes - in other words, allowing a firm to adapt. This paper focuses on adaptations to firms accounting / finance systems infrastructure. According to the accounting literature, drivers of accounting change can be identified in three broad categories, namely: (1) increasing globalization; (2) improved information technologies; and, (3) improved methods of production (Burns et al., 1999; Russel and Siegel, 1999; Scapens et al., 2003). Here, the focus of this paper is on improved information technologies and specifically on cloud computing. Oyong lisa accoding (2016) in to 
Dendawijaya (2005) defines Non-Performing Finance (NPF) is "the failure of a debtor to meet his obligations to pay installment loans which has been agreed." Wangsawidjaja (2012) argues that: "The higher non-performing Finance (NPF) is, the lower profit that a company gains due to this profit is in small enterprises". According to Mahmoeddin (2004), Non Performing Finance is basically caused by internal and external factors. External Factors is a Factor of debtors showing that not all of them have a good faith when applying for a loan or when a loan is granted under way. This kind of faith it is indeed difficult to be identified and analyzed by the bank, because it concerns with morals or morality of the debtor. It could be the debtor when applying for a loan to cover up its financial wrack and only expect fresh funds from the bank, or the debtor is providing false financial data or a variety of other actions. The second one, Iinternal Factors shows that faith is not coming from the owners. Their executives and employees of the bank are often providing credit to borrowers. Business activities do not include activities which have less obvious goals. Less obvious debtors (or can be called fictitious debtor) are those who report the actual use of funds which are different from that stated at the evidence there. According oyong lisa (2016) Capital structure with regard to multiple sources of capital can be obtained by the company to finance its operations, the company needs to establish which one to be the choice of the use of capital, in order to create a composition of the capital structure which will benefit the company. According Sudana (2011), "Capital Structure is related to a company's long-term spending as measured by the ratio of long-term debt with its own capital." Brealey et al. (2007), mention that "capital structure is a mix of long-term debt financing and equity financing", whereas Sartono (2011) states that "capital structure is balancing the amount of short-term debt that is permanent, longterm debt, preferred stock, and common stock. In fact, financial structure is the balance between total debts with its own capital. In other words, the capital structure is part of the financial structure. According Santiago Sánchez Fermín Lizarraga Dallo Laura Arnedo Ajona Manolo Cano Rodriguez , (2016, p 166-187) to We run separate regressions of price (cost of debt) and non-price (credit availability) lending decisions on different proxies for earnings quality.

Our results show that banks carry out an accounting analysis in their lending decisions, but they do it quite cursorily, that is, without taking advantage of all the possibilities offered by a comprehensive process that combines audit-based and accrual-based outcomes. Being audited by a Big $\mathrm{N}$ auditor significantly affects credit availability but not the cost of debt. As for the audit reports, banks value different qualifications depending on the lending decision studied. Only the more severe qualification (i.e. the going concern) is significantly related with lending decisions. Surprisingly, generally accepted accounting principles (GAAP) violations are not carefully screened in the process, which may be due to the difficulties in understanding the language used by the auditor. Finally, with respect to the discretionary accruals, significant relations are found with both lending decisions, but with the unexpected sign, suggesting that bank lenders do not incorporate an accrual-based quality index into their financial statement analysis, and, hence, managers gain better conditions by fooling the banks. Our results clearly support the "debt-covenant hypothesis" and are contrary to the "screening-and-rewarding" evidence found by Francis et al. (2005) and Bharath et al. (2008). This might be explained by sample-specific features such as the borrower's size or financial status. The different behaviour found between price and non-price decisions confirms the need to go beyond the cost-of-debt decision when dealing with financially troubled firms. According to El Massah, S., AlSayed, O. and Bacheer, S. (2019),Managing liquidity risk is a prerequisite for sustaining financial stability and avoiding liquidity shortages (Abdullah, 2010;Ahmed et al.,2011b;Ahmed et al.,2011a).Yet,mostof the existing instruments used for liquidity management are interest- 
based (riba), which is prohibited according to Sharia'h, and consequently, there is a lack of sufficient Sharia'h- compliant liquid instruments (Akhtar et al., 2011c).

Conventional banks use various instruments of interbank markets to meet their shortand medium-term liquidity needs (Sulaiman et al., 2013). Conversely, Islamic banks are restricted in the interbank market because of the requirement of avoiding interest-bearing instruments. They are also prohibited from borrowing on short notice through the central bank discount window, and there is no Shariah-compliant lender of last resort facility. Ray (1995) explains that one reason causing liquidity issues is the nature of financing of Islamic banks, which rely on long-term equity contracts. Alvi (2009) mentions that Islamic financial institutions can experience a shortage of liquidity because of their limited ability to acquire short-term funds. Vogel and Hayes (1998) discuss that the absence of adequate money markets or secondary capitalmmarkets for Islamic instruments leads to the problem of mismatched maturities and liquidity difficulties. As a result, Islamic banks do not have the same funding options that are available to conventional ones, which leads to exposure to liquidity risk because of the long-term illiquid assets ofIslamic banks.

\section{RESEARCH METHODS}

The research method used in this research is descriptive analysis method objective explanation especially regarding NPL to CR at PT. Bank BPR Kertaraharja and research verification that is an analysis tool that uses methods such as mathematical, statistical, and econometric models. The results of the analysis are presented in the form of numbers which are then explained and interpreted in a description. This research was conducted directly at PT. Kertaraharja BPR Bank. Jl. Raya Soreang No. 29 Kabupaten Bandung in the period of 2013 2017 or 5 years in the form of NPL and CR in a Financial Statement. The population in this study the financial statements of PT. BPR Kertaraharja Year 2013-2017. The sample used is the NPL and CR taken from the financial statements for the period of 2013 to 2017 for 5 years.

\section{FINDINGS AND DISCUSSION}

Non Performing Loans is one indicator to measure the amount of problem loans in PT. Kertaraharja BPR Bank. Based on this information, NPL Vaiabel obtained an average of $12.74 \%$ and the lowest value for the period of 2013 - 2017 was $10.15 \%$ and the highest was $15.04 \%$ and a standard deviation of $5.00 \%$ was still smaller than the average value, the lowest value and the highest there is. This shows that PT Bank BPR Kertaraharja's NPL variable data is still not good. Cash Ratio (CR) is one indicator to measure liquidity ratios. CR describes the ability of a company to generate cash from the assets used. The greater the profits generated by the company (Net Income), the greater the value of CR. A large CR value is an indication that the company is able to generate large profits by using company assets. Simple linear regression $\mathrm{Y}=35,495+2,193 \mathrm{X}$, a value of 35,495 which shows that $\mathrm{CR}$ is 35,495 while a $\mathrm{b}$ value of 2,193 indicates that when the value of CR is one unit, the NPL at PT Bank BPR Kertaraharj will increase by 2,193. Standardize Coefficients. the correlation between NPL and $\mathrm{CR}$ is 0.768 . This shows the close relationship between NPL and CR is positive. Therefore, if the NPL increases, the CR will also increase. Vice versa, if the NPL has decreased the CR will also decrease. The amount of NPL contribution or determinant coefficient is $58.98 \%$ while the remaining $41.02 \%$ is influenced by other factors. There is an influence between NPL on CR. 


\section{CONCLUSION AND SUGESTION \\ Conclusion}

NPL describes how much the company's ability to generate debt in relation to cash, assets, and capital. Where can be seen that the NPL of PT. Bank BPR Kertaraharja Tbk increased in the period 2013 to 2017 followed by an increase in the value of CR in the same period. However, in 2015 the cash flow along with the value of CR obtained decreased from the previous period. CR on PT Bank BPR Kertaraharja showed a significant increase in the period 2013 to 2017, but in the 2013 period it decreased. From the results of testing conducted the effect of NPL on CR on PT Bank BPR Kertaraharja obtained by H0 was rejected, thus there was a significant influence between NPL on CR PT. Kertaraharja BPR Bank.

\section{Recomendation}

By doing this research the authors suggest that the company's management can maintain the company's financial stability from various angles, in order to maintain the level of credit in a company to remain stable and can continue to increase. Until the customers do not hesitate to choose a company that is managed as a place to make loans. Maintaining the company's financial stability can be of various ways, such as further increasing the company's ability to generate cash, either increasing sales or optimal use of assets and capital. Hopefully the management can increase the company's NPL again in order to maintain credit stability to keep it running well.

\section{REFERENCE}

Alarussi, A. and Alhaderi, S. (2018), "Factors affecting profitability in Malaysia", Journal of Economic Studies No. 3, pp. 442-458.

Ali, Arifin, 2004. Financial management (Theory and Applications). BPFE Edition Fourth, Yogyakarta.

Dendawijaya, Lukman. 2005. Banking Management. Ghalia Indonesia, Jakarta

Dolgun, M., Ng, A. and Mirakhor, A. (2020), "Need for calibration: applying a maximum threshold to liquidity ratio for Islamic banks", International Journal of Islamic and Middle eastern Finance and Management. Vol. ahead-of-print No. ahead-of-print.

Eljelly, A. (2004), "Liquidity - profitability tradeoff: An empirical investigation in an emerging market", International Journal of Commerce and Management, Vol. 14 No. 2, pp. 48-61.

Erna Sari, Suhadak suhadak, Sri Mangesti Rahayu, Solimun Solimun, "The effects of Tier-1 capital, risk management, and profitability on performance of Indonesian commercial banks", International Journal of Law and Management. 
ElMassah, S., AlSayed, O. and Bacheer, S. (2019), "Liquidity in the UAE banks", Journal of Islamic Accounting and Business Research, Vol. 10 No. 5, pp. 679694.

Gambo, N., Said, I., \& Ismail, R. (2016). Comparing the levels of performance of small scale local government contractors in Northern Nigeria with international practice. Engineering, Construction and Architectural Management, 23(5), 588-609.

Howley, P., \& Dillon, E. (2012). Modelling the effect of farming attitudes on farm credit use: a case study from Ireland. Agricultural Finance Review, 72(3), 456-470.

Ismal, R. (2012), "Formulating withdrawal risk and bankruptcy risk in Islamic banking", ", International Journal of Islamic and Middle eastern Finance and Management. Vol. 5 No. 1, pp. 63-77.

Lisa, Oyong, (2016) "Determinants Distribution of Financing and the Implications to Profitability: Empirical Study on Cooperative Sharia Baitul Maal wa Tamwil (BMT) in Indonesia", Asian Journal of Accounting Research, Vol. 1 Issue: 2, pp.44-51,

Mavridis, D. G. (2004). The intellectual capital performance of the Japanese banking sector. Journal of Intellectual Capital, 5(1), 92-115.

Quinn , Peter Cleary Martin. (2016),"Intellectual capital and business performance - an exploratory study of the impact of cloud-based accounting and finance infrastructure", Journal of Intellectual Capital, Vol. 17 Iss 2 pp. -

Santiago, Sánchez Fermín Lizarraga Dallo Laura Arnedo Ajona Manolo Cano Rodriguez (2016),"Do banks react to earnings quality in a privately-dominated context?", Management Research: Journal of the Iberoamerican Academy of Management, Vol. 14 Iss 2 pp. $166-187$

Saif-Alyousfi, A. (2019), "Determinants of bank shareholder value: evidence from GCC countries", International Journal of Managerial Finance, Vol. ahead-of-print No. ahead-of-print.

Taba, M. I. (2018). Mediating effect of work performance and organizational commitment in the relationship between reward system and employees' work satisfaction. Journal of Management Development, 37(1), 65-75.

Yu-Thompson, Y., Lu-Andrews, R. and Fu, L. (2016), "Liquidity and corporate governance: evidence from family firms", Review of Accounting and Finance, Vol. 15 No. 2, pp. 144-173. 